DOI https://doi.org/10.36059/978-966-397-226-8-1

\title{
HISTORY AND ORIGIN \\ OF FOREIGN LANGUAGE REMOTE TEACHING
}

\author{
Kuzmenko A. O., Serdiuchenko Yu. O., Solodiuk N. V.
}

\section{INTRODUCTION}

Today, the labour market is changing quite rapidly, as well as its requirements for the level of training, so the most relevant requirements of employers to potential employees are upgrading skills, occupational retraining, the ability to quickly adapt to new technologies. Thus, the spread of information and computer technologies and telecommunication technologies around the world has led to the development of a new direction in education, namely remote education.

In this regard, education, in particular occupational education, should be more accessible to various segments of population, including young people, unemployed and low-mobility groups. Remote education environment, which is based on the use of telecommunication networks is characterized by resource intensity and interactivity and contributes to the intensification of the educational process and solves problems that cannot be adequately solved otherwise, for example: flexibility in getting consultations from academy staff members in the process of undergraduates' independent activities; work on an individual plan or on a separate section of the program, etc.

Remote education is currently considered as one of the ways to overcome the problems of "openness of education". Originating in the late 20th century, it entered the 21 st century as one of the most effective and promising training systems. The development and active spread of remote forms of self-training is an adequate response of the education systems of many countries to the processes taking place in the world.

Consortia of leading universities representing a wide range of remote education services are being set up around the world. Thus, the Association for Remote Education in the United States unites five thousand educational institutions. UNESCO is working to organize 
a virtual university, which will take place in virtual space, regardless of location and borders, without time restrictions.

In Ukraine and many other CIS countries, remote education has not been widely used until recently due to a number of objective reasons mainly due to insufficient development and low spread of technical means of new information and telecommunications technologies. Thus, there is a need to study the history and current stage of development of remote education and its implementation in the world's leading higher education institutions in order to improve the system of remote education in higher education institutions of Ukraine.

The purpose of the National Strategy for Education Development in Ukraine until 2021 is: to update the content, forms, methods and tools of teaching through the widespread introduction of modern information and telecommunications technologies and electronic content in the educational process. The priority of the development of Ukrainian education is the introduction of modern information technologies that ensure the improvement of the educational process, accessibility and efficiency of education, preparation of young people for activities in the information society ${ }^{1}$.

Currently, our country has already created technical preconditions for the widespread use of remote teaching in education. Moreover, there is a lag in the implementation of ideas to the opportunities provided by technical means. A significant number of Ukrainian higher education institutions already have existing departments, and some of them even have incorporated institutes for remote education.

\section{Historical Background of Remote Teaching in the World}

The idea of remote education is not new. With the introduction of regular and affordable postal services, which emerged in Europe in the late $18^{\text {th }}$ century, remote education began its development.

The first postage stamp was issued in England in 1840, which prompted I. Pitman to teach stenography to students

\footnotetext{
${ }^{1}$ Національна стратегія розвитку освіти в Україні на 2012-2021 роки. URL: https://zakon.rada.gov.ua/laws/show/344/2013\#Text (дата звернення: 11.10.2020). 
by mail ${ }^{2}$. In 1840, I. Pitman created a correspondence course in London in order to teach stenography through correspondence. Thus, this can be considered the first attempt to introduce remote teaching ${ }^{3}$. In 1843, a society of correspondence teaching stenography was established, where anyone could study for free ${ }^{4}$. Thus, it was Great Britain where the first experience of using remote teaching took place ${ }^{5}$.

In 1856, Ch. Toussaint and G. Lanchensteidt established an institute in Berlin, which provided teaching of foreign languages by mail ${ }^{6}$. In 1958 in the University of London, it was allowed to take exams at the academic level of all levels and all specialties (except medicine) to all who wish, regardless of the method of acquiring knowledge, including correspondence learning or self-study ${ }^{7}$. Until 1870, the University of London had a tradition of assisting students in their studies using the mail. The university conducted professional courses and courses in preparation for entrance exams to the university ${ }^{8}$. This process continued until 1950, when restrictions were imposed on engineering and pharmaceuticals ${ }^{9}$.

In 1877, the University of St Andrew in Scotland offered correspondence training for women for the title of licentiate of art, which

\footnotetext{
${ }^{2}$ Кива, Л., Л Лазаренко, Н. (2015). Передумова впровадження у навчальний процес технологічного факультету дистанційного навчання упроцесі вивчення дисциплін творчого напрямку. Актуальні питання гуманітарних наук. Серія: Педагогіка. Дрогобич. Вип. 13. С. 264.

${ }^{3}$ Пилаєва, Т. (2016) Історія розвитку дистанційної освіти в світі. Наукові записки. Педагогічні науки. Кіровоград. С. 114.

${ }^{4}$ Спицын, В. А. (2016). Дистанционное обучение в средних специальных учебных заведениях как фактор обеспечения качества подготовки специалистов : дисс. ... канд. пед. наук: 13.00.08. Волгоград, 2006. С. 15.

${ }^{5}$ Пилаєва, Т. Історія розвитку дистанційної освіти в світі. Наукові записки. Педагогічні науки. Кіровоград. С. 114.

${ }^{6}$ Радіус, О. А. (2006). Розвиток дистанційного навчання у вищих технічних навчальних закладах. Наукові прациі ОНАЗ ім. О. С. Попова. № 1. С. 144.

${ }^{7}$ Пилаєва, Т. (2016). Історія розвитку дистанційної освіти в світі. Наукові записки. Педагогічні науки. Кіровоград. С. 114.

${ }^{8}$ Розина, И. Н. (2007). Дистанционные и открытые формы обучения, организационные и методологические вопросы. Инновационные образовательные технологии. № 1(9). C. 67.

${ }^{9}$ Жевакіна, Н. (2003). 3 історії дистанційної освіти. Вісник Львівського університету. Серія педагогічна. Львів. Вип. 17. С. 135.
} 
existed for 55 years $^{10}$, and in 1873 in America, Anna Eliot Tiknor developed the mail education system for women and named it Tiknor Society ${ }^{11}$.

The rapid growth of railways in North America has stimulated the spread of correspondence education in the United States and Canada. The first mail program was offered by the University of Illinois in 1874, and in 1889 - by Queen's University in the Canadian state of Ontario (Kingston) $^{12}$. In 1891 , separate academic courses on mail began to be provided by the University of Chicago ${ }^{13}$ where in 1892 William Rainey Harper founded the first department of remote teaching. In 1911, remote teaching appeared in Australia due to the start of courses at the University of Queensland. Classes with students at Melbourne College of Education were conducted using mail, and in 1914 a postal school was arranged for children living far from regular schools. Postal schools for children also became widespread in Canada and New Zealand. In 1938, the first congress of the International Council for Correspondence Education took place in Canada (Victoria) ${ }^{14}$.

Remote education developed not only through the emergence of private correspondence schools, but also through the development of remote teaching units in classical universities. From the second half of the $19^{\text {th }}$ century to the early $20^{\text {th }}$ century, educational institutions offered advanced training and pre-examination training courses, for example, Cambridge University Correspondence College (preparation of graduates of non-accredited English colleges for bachelor's exams at the University of London) and Correspondence College in Oxford (preparation for the entrance exams to Oxford University). Apart from that, remote education

\footnotetext{
${ }^{10}$ Пилаєва, Т. (2016). Історія розвитку дистанційної освіти в світі. Наукові записки. Педагогічні науки. Кіровоград. С. 114.

${ }^{11}$ Кива, Л., Лазаренко, Н.(2015). Передумова впровадження у навчальний процес технологічного факультету дистанційного навчання упроцесі вивчення дисциплін творчого напрямку. Актуальні питання гуманітарних наук.Серія: Педагогіка. Дрогобич. Вип. 13. С. 264.

${ }^{12}$ Пилаєва, Т. (2016). Історія розвитку дистанційної освіти в світі. Наукові записки. Педагогічні науки. Кіровоград. С. 114.

${ }^{13}$ Жевакіна, Н. (2003). 3 історії дистанційної освіти. Вісник Львівського університету. Серія педагогічна. Львів. Вип. 17. С. 136.

${ }^{14}$ Пилаєва, Т. (2016). Історія розвитку дистанційної освіти в світі. Наукові записки. Педагогічні науки. Кіровоград. С. 114-115.
} 
starts gradually to be closely related to the development of new technologies, namely: the beginning of the $20^{\text {th }}$ century - the introduction of audiovisual devices in schools; 1910 - the first catalog of media instructions appeared; 1932 - Iowa State University began experimenting with remote courses ${ }^{15}$.

The ability to broadcast using technologies such as radio and television, which enhanced and added to remote education considerably, was marked as a new stage in the development of remote education. However, interaction between the teacher and the learner, or between learners, remained minimal. The Australian School for Air, founded in 1950, continues to use radio broadcasts. The New Zealand Correspondence School used broadcast media with it Broadcasts to school ${ }^{16}$.

In the $50 \mathrm{~s}$ and $60 \mathrm{~s}$ of the $20^{\text {th }}$ century, there was a rapid increase in non-traditional universities, both due to the expansion of continuous education programs and the fact that classical universities were considered as rather problematic to mass education ${ }^{17}$. The beginning of the history of modern remote education was the founding of the UK Open University in 1969. The Open University was established as an independent and autonomous university with the right to award academic degrees. The First Chancellor of the Open University D. Crowter described it as a university open to people, places, methods and ideas ${ }^{18}$. The UK government has provided significant funding for this project. Necessary curricula and programs in the disciplines were developed as well as textbooks and educational technologies ${ }^{19}$. For the first time, VCRs, CD-Rom, DVD, computer training programs, websites, etc. were

\footnotetext{
${ }^{15}$ Пилаєва, Т. (2016). Історія розвитку дистанційної освіти в світі. Наукові записки. Педагогічні науки. Кіровоград. С. 115.

${ }^{16}$ Andersen, B. \& Simpson, M. (2012). History and heritage in open, flexible, and distance education. Journal of Open, Flexible and Distance Learning. Vol. 16(2). P. 3. URL: https://files.eric.ed.gov/fulltext/EJ1080085.pdf (дата звернення: 13.10.2020).

17 Либин-Левав, А. В. (1998). Теория и практика дистанционного образования (Открытый университет Израиля): дисс. ... канд. пед. наук: 13.00.01. Москва. С. 25.

${ }^{18}$ Пилаєва, Т. (2016). Історія розвитку дистанційної освіти в світі. Наукові записки. Педагогічні науки. Кіровоград. С. 115.

${ }^{19}$ Жевакіна, Н. (2003). 3 історії дистанційної освіти. Вісник Львівського університету. Серія педагогічна. Львів. Вип. 17. С. 136.
} 
researched and used in the educational process at the Open University ${ }^{20}$. The use of the broadcast technologies is also well illustrated in the development of the UK Open University and its use of television ${ }^{21}$. At present, the UK Open University is the largest university in the country, with around 137,000 students from the UK and more than 20,000 from other countries, and it has become the basic model for open universities in other countries.

In 1987, the Distance Learning Association was established in the United States, which aimed to create common remote education strategies and promote the creation of new remote teaching technologies. About a million people study in the United States at universities which provide remote education. Among them, there are such universities as the National University of Technology, Kennedy Western University (graduates receive bachelor's and master's degrees, master's and doctoral degrees in business, finance and law without arriving in the United States), Phoenix Open University (a private university founded by the Appolo group), Western Governor's University (WGU) (founded in 1995 as a virtual university), California Virtual University (founded as an alternative to WGU). Among the oldest universities which provide remote education in Europe is the National University of Distance Education in Spain which has existed for more than 20 years and consists of 58 training centers in Spain and nine ones abroad ${ }^{22}$. The Baltic University, headquartered in Stockholm, unites 10 countries in the Baltic region. In Canada there is the Open University founded in 1972, with more than 14,000 undergraduates now studying business, art and IT. Shanghai Television University in China was also founded in 1972 and now covers more than 500,000 undergraduates. In 1974, the University of Fern (Hagen, Germany) was founded with curricula in the humanities, social sciences, economics and computer science, with more than 55,000 undergraduates. At the Dutch Open University, which was

\footnotetext{
${ }^{20}$ Пилаєва, Т. (2016). Історія розвитку дистанційної освіти в світі. Наукові записки. Педагогічні науки. Кіровоград. С. 115.

${ }^{21}$ Andersen, B. \& Simpson, M. (2012). History and heritage in open, flexible, and distance education. Journal of Open, Flexible and Distance Learning. Vol. 16(2). P. 3. URL: https://files.eric.ed.gov/fulltext/EJ1080085.pdf.

${ }^{22}$ Жевакіна, Н. (2003). 3 історії дистанційної освіти. Вісник Львівського університету. Серія педагогічна. Львів. Вип. 17. С. 137-138.
} 
founded in 1985, about 22,000 udergraduates study programs in business, economics, law and culture ${ }^{23}$. Since 1987 , there is a university in Oslo which specializes in computer and information technology and conducts remote training courses. Thirty remote training courses have been developed, some of which have been published. Undergraduates choose a place to register and study courses, and take exams where and when it is convenient for them ${ }^{24}$.

The next stage in the development of remote education dates back to 1985 , when they began to actively use information and communication technologies with two-way communication in both synchronous and asynchronous mode with the use of texts, graphics, sounds, animation, etc. Although computerized remote education was already used in some schools in the 1980s, it was not until 1993, when the World Wide Web became widespread, that computer and telecommunications systems began to play a significant role in remote education. At the end of the $20^{\text {th }}$ century, the British Association for Open and Distance Education was established in Great Britain, which task is to help in the exchange of educational materials and experience between the members, as well as to control the compliance of educational materials with educational standards. At the turn of the $20^{\text {th }}-$ $21^{\text {st }}$ century, the number of remote education institutions of various types and levels in the world exceeded 1,100. Penn State University is considered today as one of the most authoritative universities in the field of remote education. Australia also can be noted as the country which has an extensive experience in the field of remote education. There is a successful consortium of nine traditional universities - Open Learning Australia. Teaching is carried out in 150 disciplines of a higher educational institution, covering social sciences and business. In some countries, such as China, Latvia, the Netherlands, Algeria, Turkey, etc. from 10 to $25 \%$ of undergraduates study in institutions remotely ${ }^{25}$.

\footnotetext{
${ }^{23}$ Пилаєва, Т. (2016). Історія розвитку дистанційної освіти в світі. Наукові записки. Педагогічні науки. Кіровоград. С. 116-117.

${ }^{24}$ Жевакіна, Н. (2003). 3 історії дистанційної освіти. Вісник Львівського університету. Серія педагогічна. Львів. Вип. 17. С. 138.

${ }^{25}$ Пилаєва, Т. (2016). Історія розвитку дистанційної освіти в світі. Наукові записки. Педагогічні науки. Кіровоград. С. 117.
} 
In the $21^{\text {st }}$ century, remote education continues to become more and more popular. The very modern remote education mostly uses computer tools. Special educational programs are created for training (for example: Moodle, Prometheus), video conferences and online consultations are organized. We agree with Andersen B. \& Simpson M. saying that "...the possibilities of online computer-mediated education are exciting and all institutions will have to consider its effect and challenges it presents. Innovation grounded in the history and heritage of distance education could lead and radically change teaching and learning,"26.

\section{Historical Background of Remote Teaching in Ukraine}

In Ukraine, remote education has not been widely used until recently due to a number of objective reasons. It was mainly due to insufficient development and low spread of technical means of new information and telecommunication technologies. In the mid-90s in Ukraine there was a low level of informatization of society, low computer equipment of educational institutions, almost complete lack of Internet infrastructure and tools to create an information and educational environment for remote teaching, lack of own theoretical developments in the field of remote education.

Between 1995 and 2000, telecommunication didactic laboratories were established, and new methods and pedagogical technologies of remote teaching based on modern information and communication technologies started to spread in Ukraine.

In 1998, the Verkhovna Rada of Ukraine adopted the Law of Ukraine "On the National Informatization Program"27, which formulates tasks for the informatization of education and determines the directions of their implementation.

In 2000, the Ministry of Education and Science of Ukraine approved the "Concept for the Development of Remote Education

\footnotetext{
${ }^{26}$ Andersen, B. \& Simpson, M. (2012). History and heritage in open, flexible, and distance education. Journal of Open, Flexible and Distance Learning. Vol. 16(2). P. 5. URL: https://files.eric.ed.gov/fulltext/EJ1080085.pdf (дата звернення: 13.10.2020).

27 Закон України «Про національну програму інформатизації». URL: https://zakon.rada.gov.ua/laws/show/74/98-вр\#Text (дата звернення: 10.10.2020).
} 
in Ukraine" 28 , which provides for the establishment of an education system in the country, expanding the range of users of educational services, implementing lifelong learning and individualization of education.

The development of remote education in Ukraine had two fundamental stages of formation. Thus, the first stage of development of Ukrainian remote education in the course of 2001 can be marked by such activities as: 1) creation of organizational structure of the system of remote education; 2) development of legal bases and standards; 3 ) creation of material and technical base of regional and local remote education centers; 4) creation of the primary fund of remote courses and ensuring their experimental implementation; 5) development of principles of financing of remote education system; 6) implementation of pilot projects for the introduction of remote education ${ }^{29}$.

The second period of formation of remote education in Ukraine is characterized by a number of initiative proposals from higher education institutions to create a Ukrainian system of remote education, as well as by the adoption of a national program for the development of remote teaching in Ukraine ${ }^{30}$. Thus, the second stage of development of distance education in Ukraine in the course of 2002-2003 can be marked by the following: 1) full-scale deployment and implementation of remote education as a form of education equivalent to full-time, part-time and external education; 2) introduction of the system of multi-channel financing of legal entities and individuals of the remote education system; 3) development and implementation of a system of benefits for the use of computer networks and telecommunication infrastructure for components of the remote education system; 4) introduction of licensing, certification and accreditation system for institutions which provide

\footnotetext{
${ }^{28}$ Концепція розвитку дистанційної освіти в Україні від 20 грудня 2000 року. URL: http://uiite.kpi.ua/2019/06/03/1598/ (дата звернення: 13.10.2020).

${ }^{29}$ Освітній портал «Історія становлення ДО в Україні». URL: http://www.osvita.org.ua/ distance/ukraine/ (дата звернення: 13.10.2020).

${ }^{30}$ Кива, Л., Лазаренко, Н. (2015). Передумова впровадження у навчальний процес технологічного факультету дистанційного навчання упроцесі вивчення дисциплін творчого напрямку. Актуальні питання гуманітарних наук.Серія: Педагогіка. Дрогобич, 2015. Вип. 13. С. 267.
} 
remote education; 5) integration of the remote education system of Ukraine into the world system $^{31}$.

In 2004, the first "Regulation on Remote Education" was approved, on the basis of which the remote training centers were created by institutions of all levels of education. Higher education institutions offered a variety of initiatives to create a Ukrainian remote education system. Kharkiv National Technical University published Memorandum on the informational educational network "Ukrainian Remote Education". In addition, this period was devoted to many scientific developments regarding the introduction of remote education, there was an active mastery and adaptation of relevant existing program environments and the creation of their own ones ${ }^{32}$.

The period from 2005 to 2010 is notable for some difficulties in the field of remote education in Ukraine due to the problems with funding and lack of computer devices in educational institutions.

In August 2010, the Law of Ukraine "On Secondary Education" was amended and a new "Regulation on Secondary Education Institutions" was approved, as well as the Concept of the State Target Program on introduction of information and communication technologies "One Hundred Percent" to the educational process till 2015, which was approved in April 2011. Furthermore, attention was also paid to the creation of a continuous system of in-service teacher education using remote training in postgraduate education institutions ${ }^{33}$.

The current stage of development of remote education in Ukraine is characterized by: the introduction of new hardware and software to support remote training; the conduct of Internet seminars or webinars; the creation of an information and educational environment for remote

\footnotetext{
${ }^{31}$ Освітній портал «Історія становлення ДО в Україні». URL: http://www.osvita.org.ua/ distance/ukraine/ (дата звернення: 13.10.2020).

${ }^{32}$ Кива, Л., Лазаренко, Н.. (2015). Передумова впровадження у навчальний процес технологічного факультету дистанційного навчання упроцесі вивчення дисциплін творчого напрямку. Актуальні питання гуманітарних наук. Серія: Педагогіка. Дрогобич. Вип. 13. С. 268.

${ }^{33}$ Кива, Л., Лазаренко, Н. (2015). Передумова впровадження у навчальний процес технологічного факультету дистанційного навчання упроцесі вивчення дисциплін творчого напрямку. Актуальні питання гуманітарних наук. Серія: Педагогіка. Дрогобич. Вип. 13. С. 268.
} 
training; the modernization and improvement of resources to support interactivity and openness of remote education; the introduction of remote training in higher education; the creation of an online environment for the development of remote training sites, etc.

The Interregional Academy of Personal Management is a Ukrainian leader in the number of graduates who have obtained higher education remotely. The department on remote training at this higher education institution started its work in 2005 as a training subdivision that carries out educational work using the Internet and telecommunication technologies. Remote training is conducted using the Moodle system, as well as video consultations with the academy staff member. Besides, the Ukrainian Institute for Information Technologies in KPI Education was one of the first to introduce remote technologies in education in Ukraine. At the moment, its main task is the introduction of remote technologies in the process of full-time and part-time education and training courses. Many laboratories which specialize in remote training have been opened in Ukraine to investigate the implementation of various programs and can be considered as analytical centers and bases of theoretical information for other higher education institutions and organizations. For example, Problem Laboratory of Remote Training", which works in the structure of Kharkiv Polytechnic University ${ }^{34}$.

At the present stage, the right to provide remote educational services has been used almost by all higher education institutions in Ukraine. All of them apply special educational computer platforms like Moodle, ATutor or educational platforms of their own development. The following higher educational institutions providing remote educaion can be given as examples:

1) Pavlo Tychyna State Pedagogical University (the site http://dls.udpu.org.ua/ is used for full-time and part-time undergraduates (remote training);

2) Ternopil Ivan Puluj National Technical University (ATutor remote training system is used. Most of the undergraduates which are registered in the system are full-time and part-time undergraduates);

\footnotetext{
${ }^{34}$ Заболоцький, А. Ю. (2016). Сучасний стан дистанційного навчання у ВНЗ України. Вісник Дніпропетровського університету імені Альфреда Нобеля. Педагогічні науки. Дніпро. № 2(12). С. 20-21.
} 
3) Sumy State University (a self-developed remote training system is used (http://www.dl.sumdu.edu.ua);

4) National University of Water and Environmental Engineering (has a system which combines a part-time and remote training using Moodle (http://moodlenuwm.tk/moodle/);

5) Dnipropetrovsk State University of Internal Affairs (has a system which combines full-time / part-time and remote training using Moodle system (http://moodle.dduvs.in.ua);

6) Zaporizhzhia National University (has a system which combines full-time / part-time and remote training for both undergraduates and postgraduates using Moodle system (http://moodle.znu.edu.ua/);

7) Poltava University of Economics and Trade (education of undergraduates is performed remotely. The number of undergraduates is more than one thousand. The use of Moodle allows providing goodquality education (http://el.puet.edu.ua/);

8) Ivano-Frankivsk National Technical University of Oil and Gas (uses Moodle for remote training (http://dn.nung.edu.ua/);

9) Chernivtsi Trade and Economics Institute of Kyiv National Trade and Economics University (there is a laboratory on remote training problems which are investigated by academy staff members in collaboration with the IT centyк specialists).

\section{Mobile Learning as a Means of Modern Technology in Remote Education}

Speaking of remote training tools, we should not forget about the latest technical devices, namely: mobile phones, smartphones, tablets, etc.

Mobile learning is closely linked to learning mobility in the sense that undergraduates should be able to participate in educational activities without time and space constraints ${ }^{35}$. Scientists Semerikov, S., Teplitsky, I. and others define mobile learning as a modern direction in

\footnotetext{
${ }^{35}$ Семеріков, С. О., Стрюк, М. І., Моісеєнко, Н. В. (2012). Мобільне навчання: історикотехнологічний вимір. Теорія і практика організації самостійної роботи студентів вищих навчальних закладів: монографія. Кривий Ріг: Книжкове видавництво Киреєвського. C. $188-187$.
} 
development of remote education system with the use of mobile phones, smartphones, personal communicators, e-books. Mobile learning technology provides for a remote training system that includes a subsystem for access to local and remote content. Mobile learning is considered as learning that enables real-time monitoring of learning and provides high content intensity, as well as a tool for working together to improve the quality of learning ${ }^{36}$.

Moreover, Andersen, B. \& Simpson, M. added that the "use of mobile technologies enables learning in places and spaces not previousely conceived of as learning venues. These developments have the potential to be transformational and create new learning experience, and to personalize the activity of learning",37.

The use of the term 'mobile learning' began in the late 1950s and referred to the organization of mobile classes for teaching adults in remote areas. The development of technology in the 1960s and 1970s led to the transformation of the content of mobile learning, as during this period it was associated with field classes in the form of trailers, equipped with ICT tools, which were absent in educational institutions ${ }^{38}$.

Computer-based mobile learning originated with Alan Kay's Danybook project. Alan Kay, who worked at the Denver Air Force Base Randolph in the late 1950s, wrote machine code programs for EOM Burroghs 220. It was then that he faced the problem of transferring the data formulated on this computer to the computers of other bases. There were no standard formats and OS for these computers, so Alan Kay had to create microprograms that would contain all the necessary information and after running on other machines through a simple user interface would deploy the necessary data. Alan Kay called such programs

\footnotetext{
${ }^{36}$ Семеріков, С., Теплицький, І., Шокалюк, С. (2008). Мобільне навчання: історія, теорія, методика. Інновачійні технології навчання. Інформатика та інформаційні технології в навчальних закладах. № 6. С. 73.

${ }^{37}$ Andersen, B. \& Simpson, M. (2012). History and heritage in open, flexible, and distance education. Journal of Open, Flexible and Distance Learning. Vol. 16(2). P. 5. URL: https://files.eric.ed.gov/fulltext/EJ1080085.pdf (дата звернення: 13.10.2020).

${ }^{38}$ Семеріков, С. О., Стрюк, М. І., Моісеєнко, Н. В. (2012). Мобільне навчання: історикотехнологічний вимір. Теорія і практика організації самостійної роботи студентів вищих навчальних закладів: монографія. Кривий Ріг: Книжкове видавництво Киреєвського. C. 204.
} 
modules. He saw the role of the PC as an individual dynamic environment that combined all the components of the learning environment: text, graphics, animation, and even what had not yet been invented ${ }^{39}$.

In the 90 s of the $20^{\text {th }}$ century in a number of universities in Europe and Asia, mobile learning systems were developed. A significant role in this was played by the Palm Corporation, which provided grants for education under Palm OS in terms of PEP - Palm Education Pioneers project (1991-2002). The final report on the project substantiated the new types of training activities that arise in the process of using personal communicators; determined the role of personal communicators in the test control of students' knowledge; formulated the main advantages of the personal device for training; identified new forms of co-working, including in the field of modeling; showed ways to integrate mobile and traditional training. In terms of PEP project, almost all technological and pedagogical requirements for the use of personal communicators in the educational process were formulated ${ }^{40}$.

In the April 2000 issue of Computers and Education, which was one of the first studies focusing on M-Learning, Sharples discussed the potential for new designs in personal mobile technologies that could enhance lifelong learning programs and continuing adult educational opportunities $^{41}$.

In 2001, the European Commission launched MOBIlearn project under M. Sharples' leadership who defined the following conditions for the effectiveness of mobile learning: 1) constructiveness of learning, because it is a process of finding solutions to problems, which leads to

\footnotetext{
${ }^{39}$ Семеріков, С., Теплицький, І., Шокалюк, С.. (2008). Мобільне навчання: історія, теорія, методика. Інноваційні технології навчання. Інформатика та інформачійні технології в навчальних закладах. № 6. С. 74.

${ }^{40}$ Семеріков, С., Теплицький, І., Шокалюк, С. (2008). Мобільне навчання: історія, теорія, методика. Інновачійні технологї навчання. Інформатика та інформаційні технологї в навчальних закладах. № 6. С. 76-77.

${ }^{41}$ McConatha, D., Praul, M. \& Lynch, M. J. (2008). Mobile learning in higher education: An empirical assessment of a new educational tool. TOJET: the Turkish online journal of educational technology. Vol. 7(3). P. 15. URL: http://digitalcommons.wcupa.edu/anthrosoc_ facpub/4 (дата звернення: 14.10.2020).
} 
the formation of new experience; 2) internalization of learning outcomes; 3 ) dialectic process of control and reflection of learning outcomes ${ }^{42}$.

In 2004, Intel launched the Learning Always and Everywhere project, which aims to provide each student with personal access to mobile computer registers and to provide wireless communication in schools of Essex. Intel World Ahead Education is the international development of this project which was launched in Ukraine in 2008 under known as "Mobile technologies to schools" (e-learning environment - 1 student: 1 computer $)^{43}$.

The new millennium has also been marked by many scientific publications and investigations in the field of mobile learning.

In 2001, D. Abernathy in her article "Get Ready for M-Learning" provided one of the first looks at using mobile technologies in education. The author noted that the introduction of mobile learning tools does not displace the PC, but should complement corporate learning with new tools ${ }^{44}$.

In 2003, scientists P. Seppala and H. Alamaki studied the training and education of Finnish teachers in the use of mobile technologies in the classroom. In spring 2002, the pilot study was carried out at the Department of Home Economics and Craft Science in the University of Helsinki. Eleven students and five teachers took part in this project. The Educational Center for ICT made available 10 Nokia Communicator 9210s and two digital cameras. The idea of the pilot project was that the teachers and students could discuss teaching issues through the mobile devices and also use SMS-messages and digital pictures as a part of the supervising process. The supervisor (or trainee) could take digital pictures of various teacher training events, learner's actions and different teaching techniques. Pictures could be downloaded to the phone via infrared access and uploaded via web-browser to the

\footnotetext{
${ }^{42}$ Семеріков, С., Теплицький, І., Шокалюк. С. (2008). Мобільне навчання: історія, теорія, методика. Інновачійні технологї навчання. Інформатика та інформаційні технологї в навчальних закладах. № 6. С. 76.

${ }^{43}$ Семеріков, С. О., Стрюк, М. І., Моісеєнко, Н. В. (2012). Мобільне навчання: історикотехнологічний вимір. Теорія і практика організації самостійної роботи студентів вищих навчальних закладів: монографія. Кривий Ріг: Книжкове видавництво Киреєвського. C. 208.

${ }^{44}$ Abernathy, D. (2001). Get Ready for M-Learning. Training \& Development, February. P. 20-21.
} 
trainees' material bank. Furthermore, the supervisor could write down ideas and feedback to the training session and send them to the trainees. The reslut of the project was that both the trainees and teachers felt that mobile phones brought more flexibility in their use of time. Students noted that they could conduct educational activities whenever and wherever they wanted, for example, on the bus, train, or in shops ${ }^{45}$.

Scientists P. Thornton and C. Houser in 2005 studied the state of mobile learning in Japanese universities. In Japan, the Web supports mobile phones, PDAs, and other portable media devices, which are extremely wide-spread. A study was undertaken among Japanese undergraduates. Three times a day, at 9:00, 12:30 and 17:00 hours, the 44 female undergraduates were e-mailed short mini-lessons (100-word English vocabulary lessons) and vidioms (Web-site explaining English idioms). At the end of the study, the researchers emphasized the improvement of test results from $35 \%$ to $75 \%$ mobile testing compared to paper one. The result of the study showed that mobile phones can be effective tools for delivering foreign language learning materials to students. Moreover, students evaluated positively when used educational materials designed for mobile phones and test results showed that they were able to learn via this medium ${ }^{46}$.

Mc Conatha D., Praul M. \& Lynch M. J. described in their article "Mobile learning in higher educatin: An empirical assessment of a new educational tool" an evaluation on effectiveness of mobile learning, called Learning Mobile Author (LMA), on students outcomes in the US market. One hundred and twelve students in an introductory survey course in sociology at midsized state university in the Northeast were given the opportunity to use an M-Learning product developed by HotLava Software for the purpose of assisting in preparation for two scheduled exams. Students were instructed that throughout the semester they would be given access to vocabulary words and study questions of

\footnotetext{
${ }^{45}$ Seppala, P. \& Alamaki, H. (2003). Mobile learning in teacher training. Journal of Computer Assisted Learning. 2003. Vol. 19. P. 330-335. URL: https://onlinelibrary.wiley.com/ doi/epdf/10.1046/j.0266-4909.2003.00034.х (дата звернення: 10.10.2020).

${ }^{46}$ Thornton, P. \& Houser, C. (2005). Using mobile phones in English education in Japan. Journal of Computer Assisted Learning. Vol. 21. P. 225-226. URL: https://onlinelibrary.wiley.com/doi/epdf/10.1111/j.1365-2729.2005.00129.x (дата звернення: 10.10.2020).
} 
varying difficulty for review via their web-enabled cell phones. The materials were posted at various intervals prior to the two scheduled midsemester exams. Also, those materials were part of weekly lectures and class reading assignments. Students who accessed LMA were designated as exeperimental subjects and part of the experimental group. Those who used other methods to retrieve the review and study the practice information were identified as control group. As a result, those students who used the LMA web-enabled cell phones to retrieve and review the practice material provided for the two mid semester tests in the course had an average for the two tests of $89 \%$ and those who used only the printed or discussion sources had an overall average of $84 \%$. Taking into account the aforementioned, we may conclude that incorporating mobile technologies into educational process can capture undergratuates' attention while studying and benefit their knowledge.

Thus, today the attention to mobile learning continues to grow, as evidenced by the large number of conferences, seminars, scientific publications and manuals. Undoubtedly, mobile learning is playing an increasingly important role in modernizing and improving Ukrainian education. That is why higher education institutions in Ukraine should focus on improving the educational services provided by gradually including mobile learning approaches in the educational process.

\section{Foreign language remote teaching in Ukraine}

Regarding the study of foreign language remote teaching, it should be noted that in general it focuses on the effectiveness of communication skills, technological aspects of language learning and autonomous learning. For example, there are two approaches to remote teaching of a foreign language based on the practice of four communication skills, the development of appropriate assessment strategies and the contribution of undergraduates to the educational process. They analyze the philosophies of e-learning between the two universities, which explain some common features and differences. They concluded that

\footnotetext{
${ }^{47}$ McConatha, D., Praul, M. \& Lynch, M. J. (2008). Mobile learning in higher education: An empirical assessment of a new educational tool. TOJET: the Turkish online journal of educational technology. Vol. 7(3). P. 19-20. URL: http://digitalcommons.wcupa.edu/ anthrosoc_facpub/4 (дата звернення: 14.10.2020).
} 
each university provides quality courses to undergraduates, but the writers point out that institutions wishing to conduct remote teaching should reconsider their capabilities and technological support.

The experience of using foreign language remote teaching is growing along with the number of universities in Ukraine today. Leaders in this field are: Sumy State University, National University "Lviv Polytechnic", Kyiv Polytechnic University, Kharkiv National Automobile and Road University, Drahomanov National Pedagogical University, Khmelnytsky National University, Kherson State University, Luhansk Taras Shevchenko National University, Kryvyi Rih National University.

The UDL System organization operates in Ukraine. This partner organization brings together universities, banks, corporations, research institutes and non-profit organizations to improve technology and train new professionals to develop remote teaching. There are also other organizations, for example: The Ukrainian scientific online community and The methodological association of distance learning teachers.

\section{CONCLUSIONS}

Considering the historical path of development and implementation of remote teaching, it can be conclude that this form of teaching began to be used at the end of the $18^{\text {th }}$ century due to the emergence of regular and reliable mail. This form of education was called correspondence education, which was used by many higher education institutions around the world.

With radio and television, remote education got to a new level. Beginning in the 1950s, educational programs, which gathered a wide audience, began to be broadcast. However, television and radio had such a drawback as the lack of feedback.

In 1969, the university of remote education, called the Open University, was founded in Great Britain. The University got its name to show its affordability due to the low cost of training and no need of frequent classroom attendance. Following the Open University, many universities have been opened in the world, which provide educational services remotely, and the Open University of Great Britain has become for them a basic model for organizing the remote educational process. 
In today's world, remote education is becoming increasingly popular. For instance, in some countries, such as China, Latvia, the Netherlands, Algeria, Turkey, etc. from 10 to $25 \%$ of undergraduates study in institutions remotely.

Remote teaching is a new educational standard that has appeared in Ukraine recently, but has already won its place in the pedagogical environment. Computerization in Ukraine began in 1997, which led to the development and implementation of remote education. Today, remote teaching technologies are widely used in higher education institutions of Ukraine and various educational platforms, such as Moodle, or self-developed platforms are applied.

Special attention should be paid to mobile learning with the use of technical means such as mobile phones, smartphones and tablets which is defined as a modern direction in development of remote education and considered as learning that enables real-time monitoring of learning and provides high content intensity.

\section{SUMMARY}

The article deals with the peculiarities of historical development of remote teaching. It has been determined that the idea of remote education is not new and is one the most popular ways of learning and teaching in the modern world. Initially, remote teaching was started as correspondence education for representatives of different classes of the population, who could learn only in their free time. Gradually, universities began to develop programs for remote courses, and training was carried out using the mail. With the development of new technologies and introduction of radio and television, remote teaching methods have changed and become more affordable to people.

Currently, higher education institutions in Ukraine and around the world use the most modern technical means, including mobile devices, to provide remote teaching services. The article emphasizes on the importance of remote education in the modern world based on the historical background of its development. 


\section{REFERENCES}

1. Заболоцький, А. Ю. (2016). Сучасний стан дистанційного навчання у ВНЗ України. Вісник Дніпропетровського університету імені Альфреда Нобеля. Педагогічні науки. Дніпро. № 2(12). С. 19-23.

2. Закон України «Про національну програму інформатизації». URL: https://zakon.rada.gov.ua/laws/show/74/98-вр\#Text (дата звернення: 10.10.2020).

3. Концепція розвитку дистанційної освіти в Україні від 20 грудня 2000 року. URL: http://uiite.kpi.ua/2019/06/03/1598/ (дата звернення: 13.10.2020).

4. Кива, Л., Лазаренко, Н. (2015). Передумова впровадження у навчальний процес технологічного факультету дистанційного навчання у процесі вивчення дисциплін творчого напрямку. Актуальні питання гуманітарних наук. Серія : Педагогіка. Дрогобич. Вип. 13. C. $262-270$.

5. Либин-Левав, А. В. (1998). Теория и практика дистанционного образования (Открытый университет Израиля) : дисс.... канд. пед. наук: 13.00.01. Москва. 220 с.

6. Національна стратегія розвитку освіти в Україні на 2012-2021 роки. URL: https://zakon.rada.gov.ua/laws/show/344/2013\#Text (дата звернення: 10.10.2020).

7. Жевакіна, Н. (2003). 3 історії дистанційної освіти. Вісник Львівського університету. Серія педагогічна. Львів. Вип. 17. С. 135-141.

8. Освітній портал «Історія становлення ДО в Україні». URL: http://www.osvita.org.ua/distance/ukraine/ (дата звернення: 13.10.2020).

9. Радіус, О. А. (2006). Розвиток дистанційного навчання у вищих технічних навчальних закладах. Наукові праиі ОНАЗ ім. О. С. Попова. № 1. C. 144-147.

10. Розина, И. Н. (2007). Дистанционные и открытые формы обучения, организационные и методологические вопросы. Инновачионные образовательные технологии. № 1(9). С. 60-74.

11. Семеріков, С., Теплицький, І., Шокалюк, С. (2008) Мобільне навчання: історія, теорія, методика. Інноваційні технологї навчання. Інформатика та інформаційні технологї в навчальних закладах. № 6. C. $72-82$.

12. Семеріков, С. О., Стрюк, М. I., Моісеєнко, Н. В. (2012). Мобільне навчання: історико-технологічний вимір. Теорія і практика організації самостійної роботи студентів вищих навчальних закладів : 
монографія. Кривий Ріг : Книжкове видавництво Киреєвського. C. $188-242$.

13. Спицын, В. А. (2006). Дистанционное обучение в средних специальных учебных заведениях как фактор обеспечения качества подготовки специалистов : дисс. ... канд. пед. Наук : 13.00.08. Волгоград. 193 с.

14. Пилаєва, Т. (2016). Історія розвитку дистанційної освіти в світі. Наукові записки. Педагогічні науки. Кіровоград. С. 114-118.

15. Abernathy, D. (2001). Get Ready for M-Learning. Training \& Development, February. P. 20-21.

16. Andersen, B. \& Simpson, M. (2012). History and heritage in open, flexible, and distance education. Journal of Open, Flexible and Distance Learning. Vol. 16(2). P. 1-10. Retrieved from https://files.eric.ed.gov/ fulltext/EJ1080085.pdf (дата звернення: 13.10.2020).

17. McConatha, D., Praul, M. \& Lynch, M. J. (2008). Mobile learning in higher education: An empirical assessment of a new educational tool. TOJET: the Turkish online journal of educational technology. Vol. 7(3). P. 15. URL: http://digitalcommons.wcupa.edu/anthrosoc_facpub/4 (дата звернення: 14.10.2020).

18. Seppala, P. \& Alamaki, H. (2003). Mobile learning in teacher training. Journal of Computer Assisted Learning. 2003. Vol. 19. P. 330-335. URL: https://onlinelibrary.wiley.com/doi/epdf/10.1046/j.0266-4909.2003. 00034.x (дата звернення: 10.10.2020).

19. Thornton, P. \& Houser, C. (2005). Using mobile phones in English education in Japan. Journal of Computer Assisted. Vol. 21. P. 217-228. URL: $\quad$ https://onlinelibrary.wiley.com/doi/epdf/10.1111/j.1365-2729.2005. 00129.x (дата звернення: 10.10.2020). 